\title{
Anti-cancer effects of Kaempferia parviflora on ovarian cancer SKOV3 cells
}

\author{
Suthasinee Paramee ${ }^{1,2}$, Siriwoot Sookkhee ${ }^{3}$, Choompone Sakonwasun ${ }^{3}$, Mingkwan Na Takuathung ${ }^{1}$, \\ Pitchaya Mungkornasawakull ${ }^{4,5}$, Wutigri Nimlamool ${ }^{1}$ and Saranyapin Potikanond ${ }^{1 *}$ (i)
}

\begin{abstract}
Background: Kaempferia parviflora (KP) is an herb found in the north of Thailand and used as a folk medicine for improving vitality. Current reports have shown the anti-cancer activities of KP. However, the anti-cancer effects of KP on highly aggressive ovarian cancer have not been investigated. Therefore, we determined the effects of KP on cell proliferation, migration, and cell death in SKOV3 cells.
\end{abstract}

Methods: Ovarian cancer cell line, SKOV3 was used to investigate the anti-cancer effect of KP extract. Cell viability, cell proliferation, MMP activity, cell migration, and invasion were measured by MTT assay, cell counting, gelatin zymography, wound healing assay, and Transwell migration and invasion assays, respectively. Cell death was determined by trypan blue exclusion test, AnnexinV/PI with flow cytometry, and nuclear staining. The level of ERK and AKT phosphorylation, and caspase-3, caspase-7, caspase-9 was investigated by western blot analysis.

Results: KP extract was cytotoxic to SKOV3 cells when the concentration was increased, and this effect could still be observed even though EGF was present. Besides, the cell doubling time was significantly prolonged in the cells treated with KP. Moreover, KP strongly suppressed cell proliferation, cell migration and invasion. These consequences may be associated with the ability of KP in inhibiting the activity of MMP-2 and MMP-9 assayed by gelatin zymography. Moreover, $\mathrm{KP}$ at high concentrations could induce SKOV3 cell apoptosis demonstrated by AnnexinV/PI staining and flow cytometry. Consistently, nuclear labelling of cells treated with KP extract showed DNA fragmentation and deformity. The induction of caspase-3, caspase-7, and caspase-9 indicates that KP induces cell death through the intrinsic apoptotic pathway. The antitumor activities of KP might be regulated through PI3K AKT and MAPK pathways since the phosphorylation of AKT and ERK1/2 was reduced.

Conclusions: The inhibitory effects of KP in cell proliferation, cell migration and invasion together with apoptotic cell death induction in SKOV3 cells suggest that KP has a potential to be a new candidate for ovarian cancer chemotherapeutic agent.

Keywords: Kaempferia parviflora, Thai black ginger, Ovarian cancer, Anti-cancer activity

\section{Background}

Ovarian cancer is one of the three common gynecological cancers worldwide after cervical and uterine cancers [1]. However, it is the most leading cause of death among these three gynecologic cancers [2]. Compared to others, ovarian cancer has the poorest prognosis, with the five-year survival rate of $44 \%$ for all stages [3]. Up to $70 \%$ of all ovarian cancer cases are high-grade carcinomas

\footnotetext{
* Correspondence: saranyapin.p@cmu.ac.th; spotikanond@gmail.com 1 Department of Pharmacology, Faculty of Medicine, Chiang Mai University, Chiang Mai 50200, Thailand

Full list of author information is available at the end of the article
}

which grow aggressively, metastasize rapidly, and have high chromosomal instability $[4,5]$. Asymptomatic or non-specific symptoms at an early stage together with poor screening method makes ovarian cancer a late diagnostic tumor. Chemotherapeutic drugs are treatment choices for unresectable tumor. However, they have many side effects including hair loss, fatigue, bone marrow suppression, and bleeding which can lower the quality of patient life [6]. Even though many new chemotherapeutics have been developed, the drugs are less accessible for many patients due to their high cost. We hope that our findings of effective medicinal plant tested in vitro

(c) The Author(s). 2018 Open Access This article is distributed under the terms of the Creative Commons Attribution 4.0 International License (http://creativecommons.org/licenses/by/4.0/), which permits unrestricted use, distribution, and reproduction in any medium, provided you give appropriate credit to the original author(s) and the source, provide a link to the Creative Commons license, and indicate if changes were made. The Creative Commons Public Domain Dedication waiver (http://creativecommons.org/publicdomain/zero/1.0/) applies to the data made available in this article, unless otherwise stated. 
may be an important step valuable for pacing into the next level of drug discovery and to be a complementary option with reasonable cost for patients with ovarian cancer.

Kaempferia parviflora (KP) is a Thai traditional plant in the Zingiberaceae family. It is commonly known as Thai black ginger or in Thai as "Krachai dum". KP has been previously demonstrated to have several pharmacological effects including anti-plasmodial, anti-fungal, anti-mycobacterial [7], and anti-cancer properties [7-9]. We previously described the anti-cancer property of KP against cervical cancer HeLa cells showing the promising possibility that KP may be used as a potential agent for cervical cancer treatment [10]. However, the anti-cancer effects of KP against ovarian cancer have not yet been reported. This leads us to investigate anti-cancer properties of KP against a high-grade ovarian cancer cell line, SKOV3, which is highly resistant to many cytotoxic agents. Since epidermal growth factor receptor (EGFR), is strongly expressed in ovarian cancer [11] and involved in cell proliferation, cell migration, cell survival, and metastasis, we therefore examined the effects of KP on SKOV3 alone and under the influence of EGF to verify whether KP can overcome the EGF-dependent growth and survival signal transduction pathways. Nevertheless, the molecular mechanisms of how KP suppresses tumor growth and survival were also explored. In particular, the effects of KP on the PI3K/AKT and MAPK pathways which are important signal transduction pathways for tumorigenesis [12, 13] were defined.

\section{Methods}

\section{Cell culture}

Human ovarian cancer SKOV3 cells were obtained from ATCC (ATCC, Manassas, VA, United States) and maintained in (Roswell Park Memorial Institute) RPMI-1640 medium (Gibco, BRL, USA) supplemented with 10\% fetal bovine serum (FBS) (Gibco BRL, USA) and antibiotics (100 U/mL penicillin and $100 \mu \mathrm{g} / \mathrm{mL}$ streptomycin) (Caisson, USA) and incubated at $37{ }^{\circ} \mathrm{C}$ in a humidified atmosphere, $5 \% \mathrm{CO}_{2}$. The cells were sub-cultured every 2-3 days.

\section{Extraction of Kaempferia parviflora rhizomes}

The rhizomes of Kaempferia parviflora with voucher specimen number (R-CMUKP002) authenticated by Dr. Angkhana Inta and deposited at the Faculty of Science, Chiang Mai University, Thailand, were harvested from the CMU-RSPG Kaempferia housing at Chiang Dao, Chiang Mai Province, Thailand. For the extraction, chopped rhizomes of the plant were extracted with $95 \%$ ethanol at room temperature (RT) for 3 days and filtered before concentrated using a rotary evaporator. After solvent evaporation, the plant ethanolic extraction yielded $9.85 \%$ dry weight of KP rhizomes. One milliliter of DMSO was used to dissolve $1 \mathrm{~g}$ of KP extract to make a $1 \mathrm{~g} / \mathrm{mL}$ stock solution. The KP stock was pre-diluted in medium prior to each treatment. Each experiment was performed with three independent batches of KP extract, each assayed in triplicate. The final concentration of DMSO was maintained below $0.5 \% \mathrm{v} / \mathrm{v}$ throughout the experiment.

\section{Cell viability assay}

The cytotoxicity of KP on SKOV3 cells was determined by MTT (3-(4, 5-dimethylthiazol-2-yl)-2, 5-diphenyl tetrazolium bromide). Cells were seeded at a density of $1 \times 10^{4}$ cells per well in 96-well plates overnight and treated with KP or DMSO (vehicle control 0.006-0.1\%) in quadruplicate. For the treatment group, cells were incubated with complete media containing different concentrations of KP extract, ranging from 0 to $10 \mathrm{mg} / \mathrm{mL}$ with or without the presence of $100 \mathrm{ng} / \mathrm{ml}$ of EGF. After $24 \mathrm{~h}$, cells were incubated with $0.5 \mathrm{mg} / \mathrm{mL}$ MTT reagent (Applichem GmbH, Germany) for 1-3 h. The culture supernatant was aspirated and $100 \mu \mathrm{l}$ of DMSO was added to each well. The absorbance was measured at 570 nm using Synergy ${ }^{\text {TM }}$ H4 Hybrid Multi-Mode Microplate Reader. Cell viability assay was performed in 3 individual experiments.

\section{Cell counting}

Cells were seeded in 24-well plates at a density of $0.05 \times$ $10^{6}$ cells/well in culture media and incubated for $24 \mathrm{~h}$ at $37{ }^{\circ} \mathrm{C}, 5 \% \mathrm{CO}_{2}$. Cells were treated with $\mathrm{KP}$ extract at non-toxic concentrations (0.01, 0.025, and $0.05 \mathrm{mg} / \mathrm{mL})$. The total number of cells at different time points $(0,24$, 48, 72 and $96 \mathrm{~h}$ ) was counted using a haemacytometer. The doubling time of the cell was calculated according to the following formula: Doubling time $=($ Time $\times \log 2) /$ (log(final number)-log(initial number)).

\section{Gelatin zymography}

The activity of MMP-2 and MMP-9 was examined using gelatin zymography. The sample culture supernatants of SKOV3 cells $\left(1 \times 10^{6}\right.$ cells in a $3-\mathrm{cm}$ dish $)$ incubated with different concentrations of KP extract $(0,0.01,0.05$, and $0.1 \mathrm{mg} / \mathrm{mL}$ ) with or without the presence of EGF (100 ng/mL) for $24 \mathrm{~h}$ were collected. The sample culture supernatants were separated in $10 \%$ sodium dodecyl sulfate polyacrylamide gel electrophoresis (SDS-PAGE) containing $0.1 \mathrm{mg} / \mathrm{mL}$ of gelatin B (Bio-Rad Laboratories, Hercules, California, USA) under a non-reducing condition in cold running conditions. After electrophoresis, the gels were incubated with $2.5 \%$ Triton X-100 twice (for $30 \mathrm{~min}$ each), at RT and washed with $10 \mathrm{mM}$ Tris buffer, $\mathrm{pH} 8.0$ for $2 \mathrm{~min}$. The gels were incubated with $1 \%$ gelatinase buffer (50 mM Tris $\mathrm{HCl}, 10 \mathrm{mM} \mathrm{CaCl}_{2}, \mathrm{pH} \mathrm{8}$ ) overnight at $37^{\circ} \mathrm{C}$. The gels were stained with $0.5 \%(\mathrm{w} / \mathrm{v})$ Coomassie brilliant blue R250 (Bio-Rad Laboratories) in 50\% methanol and 
$10 \%$ glacial acetic acid for $30 \mathrm{~min}$ and destained with a destaining solution (10\% acetic acid and 50\% methanol). Proteolytic activities of MMP-2 and MMP-9 were visualized as clear zone bands on a blue background and analyzed using ImageJ software.

\section{Wound healing assay}

SKOV3 cells $\left(0.5 \times 10^{6}\right.$ cells/well $)$ were seeded and cultured in 24-well plates for $24 \mathrm{~h}$. A scratch wound was made by using $200 \mathrm{~mL}$ pipette tip. Cells were treated with different concentrations of KP extract $(0.01,0.05$, and $0.1 \mathrm{mg} / \mathrm{mL}$ ) for $24 \mathrm{~h}$. Images of the scratched wounds were captured at different time points $(0,12$, and $24 \mathrm{~h})$. The closing of scratched wounds was considered to be the completion of the migration process. The migrated areas were analyzed and determined using the Image J software.

\section{Cell migration}

A Cell Culture Insert $(8 \mu \mathrm{m})$ (SPL Life Sciences, South Korea) was used to confirm the effect of KP on suppressing cell migration. Cells at a density of $0.3 \times 10^{6}$ cells/well were seeded in the upper chambers and cultured in serum-free media for $24 \mathrm{~h}$. The next day cells in the upper chamber were treated with different concentrations $(0,0.01,0.05$, and $0.1 \mathrm{mg} / \mathrm{mL}$ ) of KP in serum free media (SFM), and the upper chambers were put into the (lower) wells containing RPMI with 5\% FBS and incubated for $24 \mathrm{~h}$. Absolute methanol was used to fix cells for $5 \mathrm{~min}$ at RT, and cells were then stained with $0.5 \%$ crystal violet for $30 \mathrm{~min}$. The upper chambers were washed for 3 times with water, and cells attached to the surface inside the chamber were removed with a cotton swab and the stained cells attached at the other site of the chamber were captured and analyzed with the ImageJ software.

\section{Cell invasion assay}

The effects of KP on SKOV3 cell invasion were determined using Cell Culture Inserts (SPL life sciences, Korea). The polycarbonate invasion chambers ( $8 \mu \mathrm{m}$ pore size) were coated with Matrigel $^{\circledR}$ Matrix (356,234, Lot 4,272,006, Corning, Bedford, USA) per well and incubated at RT for $1-4 \mathrm{~h}$. Cells, at a density of $0.25 \times 10^{6}$ cells per well, were seeded on Matrigel with 0.01 and $0.05 \mathrm{mg} / \mathrm{mL}$ of $\mathrm{KP}$ in serum-free media and the invasion chambers were put into the wells (the lower) containing RPMI with 10\% FBS and incubated for $20 \mathrm{~h}$. Cells were then fixed with absolute methanol for $5 \mathrm{~min}$ at RT and stained with $0.5 \%$ crystal violet for $15 \mathrm{~min}$. After three washes with water, cells in the invasion chambers were removed with cotton swab and the pictures of the stained cells attached at the other site of the invasion chamber were taken and analyzed with ImageJ software.

\section{Trypan blue exclusion test}

Cells were seeded at a density of $0.05 \times 10^{6}$ cells/well in 24-well plates and incubated with different cytotoxic concentrations $(0,0.05,0.1$, and $0.25 \mathrm{mg} / \mathrm{mL})$ of $\mathrm{KP}$ extract. Cells were harvested after $3,6,12,24$, and $48 \mathrm{~h}$ of incubation. Trypan blue solution (Gibco, USA) was added to the cell suspensions in a ratio of 1:1. Total cells and dead cells (stained in blue) were counted using haemacytometer. The percentage of living cells and dead cells was calculated.

\section{Cell apoptosis assay}

Cell apoptosis was assessed by annexin-V-FITC/propidium iodide $(\mathrm{PI})$ staining. Cells were seeded at a $0.3 \times$ $10^{6}$ cells/well density in $3-\mathrm{cm}$ cell culture dishes and cultured for $24 \mathrm{~h}$. Cells were treated with different concentrations of KP extract $(0,0.1,0.3$, and $0.5 \mathrm{mg} / \mathrm{mL})$ for $12 \mathrm{~h}$. Cells were harvested and resuspended in $1 \mathrm{X}$ annexin-V binding buffer (50 mM Tris- $\mathrm{HCl}$ ( $\mathrm{pH} 7.5), 5 \mathrm{mM}$ EDTA, $0.5 \mathrm{mM}$ DTT, 50\% glycerol). Cells were incubated with annexin V-FITC (ImmunoTools, Germany) and propidium iodide (PI) (Sigma Aldrich) for $15 \mathrm{~min}$ in the dark at RT before performing flow cytometry.

\section{Nuclear staining}

SKOV3 cells were seeded at a density of $0.5 \times 10^{6}$ cells/well on glass coverslips for $24 \mathrm{~h}$. Cells were treated with $\mathrm{KP}$ extract at different concentrations $(0.1,0.3$, and $0.5 \mathrm{mg} / \mathrm{mL})$ and incubated for $7 \mathrm{~h}$. Cells were fixed with $4 \%$ paraformaldehyde/PBS at RT for $15 \mathrm{~min}$. Then, cells were washed thrice and incubated with $5 \mu \mathrm{g} / \mathrm{mL}$ of Hoechst 33342 in PBS (Thermo Fisher Scientific. Thailand) for $1 \mathrm{~h}$. Following staining, the sample slides were washed twice with PBS for 5 min each time, and the sample slides were mounted using Fluoromount media (SouthernBiotech, United States). Cells were observed by a fluorescent microscope, AX70 Olympus $\mathrm{R}$, Japan, with 40X magnification, and micrographs were captured with the DP-BSW Basic Software for the DP71 microscope digital camera.

\section{Western blot analysis}

SKOV3 cells were seeded in 3-cm dishes at a density of $0.3 \times 10^{6}$ cells/well for $24 \mathrm{~h}$. The next day, media were changed to SFM and cells were cultured for $24 \mathrm{~h}$. Cells were treated with KP extract at non-toxic concentrations $(0.01$ and $0.05 \mathrm{mg} / \mathrm{mL}$ ) for $6 \mathrm{~h}$ and $100 \mathrm{ng} / \mathrm{mL}$ of EGF was added to the wells $15 \mathrm{~min}$ before harvesting cells. Cell lysates were prepared by adding $300 \mu \mathrm{L}$ of $1 \mathrm{X}$ reducing Laemmli buffer and heating at $95{ }^{\circ} \mathrm{C}$ for $5 \mathrm{~min}$. Cell lysates were separated by SDS-PAGE for $90 \mathrm{~min}$ at $140 \mathrm{~V}$ and transferred to PVDF membranes (Immobilon-P; Millipore, Bedford, MA) for $120 \mathrm{~min}$ at $100 \mathrm{~V}$. After electrophoresis, membranes were blocked with $5 \%$ skim milk in TBS containing $0.1 \%$ tween-20 (TBST) at RT for $1 \mathrm{~h}$. The blots were incubated with primary antibodies (1:10000 
of anti- $\beta$-actin, $1: 5000$ of anti-pERK1/2, 1:5000 of anti-pAKT, 1:5000 of anti-ERK1/2, 1:5000 of anti-AKT, $1: 3000$ of caspase- 3 , or caspase-7, or caspase-9) at $4{ }^{\circ} \mathrm{C}$ overnight. Anti- $\beta$-actin was obtained from US biological (USA) and the remaining antibodies were purchased from Cell Signaling Technology (USA). The membranes were washed and incubated with an anti-mouse Ig conjugated with IRDye $800 \mathrm{CW}$ (1:5000) or an anti-rabbit Ig conjugated with IRDye $680 \mathrm{RT}$ (1:5000) at RT for $2 \mathrm{~h}$. The immunoreactive bands were visualized by Odyssey ${ }^{\circ}$ CLx Imaging System - LI-COR Biosciences (USA). The bands were analyzed using Image Studio Lite.

\section{Statistical analysis}

Data are presented as mean \pm SD. Data were analyzed by one-way ANOVA and $P$-value $<0.05$ was considered statically significant.

\section{Results \\ The effect of KP on SKOV3 cell viability and cell proliferation}

To investigate antitumor properties of KP, we first evaluated its cytotoxicity to SKOV3 by using MTT assay. We found that cells treated with $\mathrm{KP}$ extract at different concentrations (0.006-1 $\mathrm{mg} / \mathrm{mL}$ ) for $24 \mathrm{~h}$ showed significant reduction in cell viability in a concentration-dependent manner from the range of $0.09 \mathrm{mg} / \mathrm{mL}$ to $1 \mathrm{mg} / \mathrm{mL}$ as shown in Fig. 1a. The half maximal inhibitory concentration (IC50) of KP extract was $0.53 \pm 0.08 \mathrm{mg} / \mathrm{mL}$. Since epidermal growth factor receptor (EGFR), which is highly expressed in ovarian cancer cells, is a very important factor for tumor growth [11], we therefore stimulated SKOV3 cells with EGF and performed MTT assay to evaluate whether KP still be able to suppress cell viability. As shown in Fig. 1b, EGF significantly increased cell viability approximately $15 \%$. Interestingly, in the presence of EGF, KP still exhibited strong growth suppression in a concentration-dependent manner. The vehicle control, DMSO, at all concentrations, did not show any cytotoxic effect. The IC50 of KP extract in the presence of EGF was $0.63 \pm 0.08 \mathrm{mg} / \mathrm{mL}$ which is similar to the IC50 of KP treatment without EGF. We further performed cell counting at 24, 48, 72, $96 \mathrm{~h}$ after KP treatment and found that KP extract significantly reduced the number of cells in a concentration-dependent manner (Fig. 2). These observations were still seen in the treatment with the presence of EGF. The number of cell from different time points were used to calculate the doubling time which is the time required for cell dividing from one to two cells. The doubling time of SKOV3 cell was approximately $24 \mathrm{~h}$. Interestingly, cells treated with KP at 0.025 and $0.05 \mathrm{mg} / \mathrm{mL}$ significantly increased cell doubling time to $32.6 \mathrm{~h}$, and $31.5 \mathrm{~h}$, respectively.

\section{The effect of KP on inhibiting MMP-9 and MMP-2 activities}

We next determined whether KP extract suppresses MMP-9 and MMP-2 activities. Data from zymographic analysis showed that cells treated with KP extract at 0.01 and $0.05 \mathrm{mg} / \mathrm{mL}$ reduced MMP-9 activity to $92.52 \pm$ $8.55 \%$ and $81.92 \pm 5.18 \%$ and MMP-2 activity to $88.66 \pm$ 6.17 and $68.83 \pm 6.17 \%$, respectively (Fig. 3a and b). EGF at $100 \mathrm{ng} / \mathrm{mL}$ strongly increased MMP-2 and MMP-9 activities over $140 \%$. As we expected, KP extract with the presence of EGF was still able to suppress MMP-9 and MMP-2 activities. The percent reduction of MMP-9 activity was $113.97 \pm 10.7$ and $106.64 \pm 9.9 \mathrm{mg} / \mathrm{mL}$ and MMP-2 activity was $121.4 \pm 4.7$ and $104.01 \pm 10.12 \mathrm{mg} / \mathrm{mL}$ for cell treated with $\mathrm{KP}$ at 0.01 and $0.05 \mathrm{mg} / \mathrm{mL}$, respectively. The immunoreactive bands of $\beta$-actin detected by western indicated the equal amount of cells in all treated groups.

The effect of KP on inhibiting cell migration and invasion Based on the fact that MMP-9 and MMP-2 are crucial factors for tumor migration and metastasis, we therefore performed wound healing assay to examine cell migration and found that cells treated with KP at 0.01, 0.05, and $0.1 \mathrm{mg} / \mathrm{mL}$ effectively reduced the percent of cell migration to $58.30 \pm 5.8,52.91 \pm 5.32$, and $40.50 \pm 9.27 \%$, respectively (Fig. 4a and b). Moreover, we confirmed the ability of KP in inhibiting cell migratory function of SKOV3 cells with Transwell migration assay. The results showed that SKOV3 cells without any treatment could migrate through the upper well to the lower chamber. However, the number of migrated cells was drastically decreased in cells treated with KP extract whereas the vehicle control did not show any inhibitory effect on SKOV3 cell migration (Fig. 4c and d). The effect of KP on cell invasion was determined by using Transwell assay with the presence of matrigel. Similar to cell migration assay, cells treated with KP 0.01 and $0.05 \mathrm{mg} / \mathrm{mL}$ showed a decrease in percent cell invasion to $44.42 \pm 2.37 \%$, and $30.46 \pm 2.23 \%$, respectively (Fig. 4 e and f) while the DMSO vehicle did not show significant inhibitory effect on cell invasion.

\section{The effect of KP on inhibiting growth and survival signal transduction pathways}

Several signaling molecules are involved in cell growth and survival processes in response to EGF stimulation. Those molecules include ERK1/2 and AKT proteins. We therefore investigated the possible underlying mechanism of KP that suppresses growth in SKOV3 cells. As shown in Fig. 5, we found that cells treated with KP at 0.01 and $0.05 \mathrm{mg} / \mathrm{mL}$ exhibited reduction in ERK1/2 phosphorylation to $0.85 \pm 0.02$ and $0.64 \pm 0.031$, respectively. Even though EGF strongly activated ERK1/2 

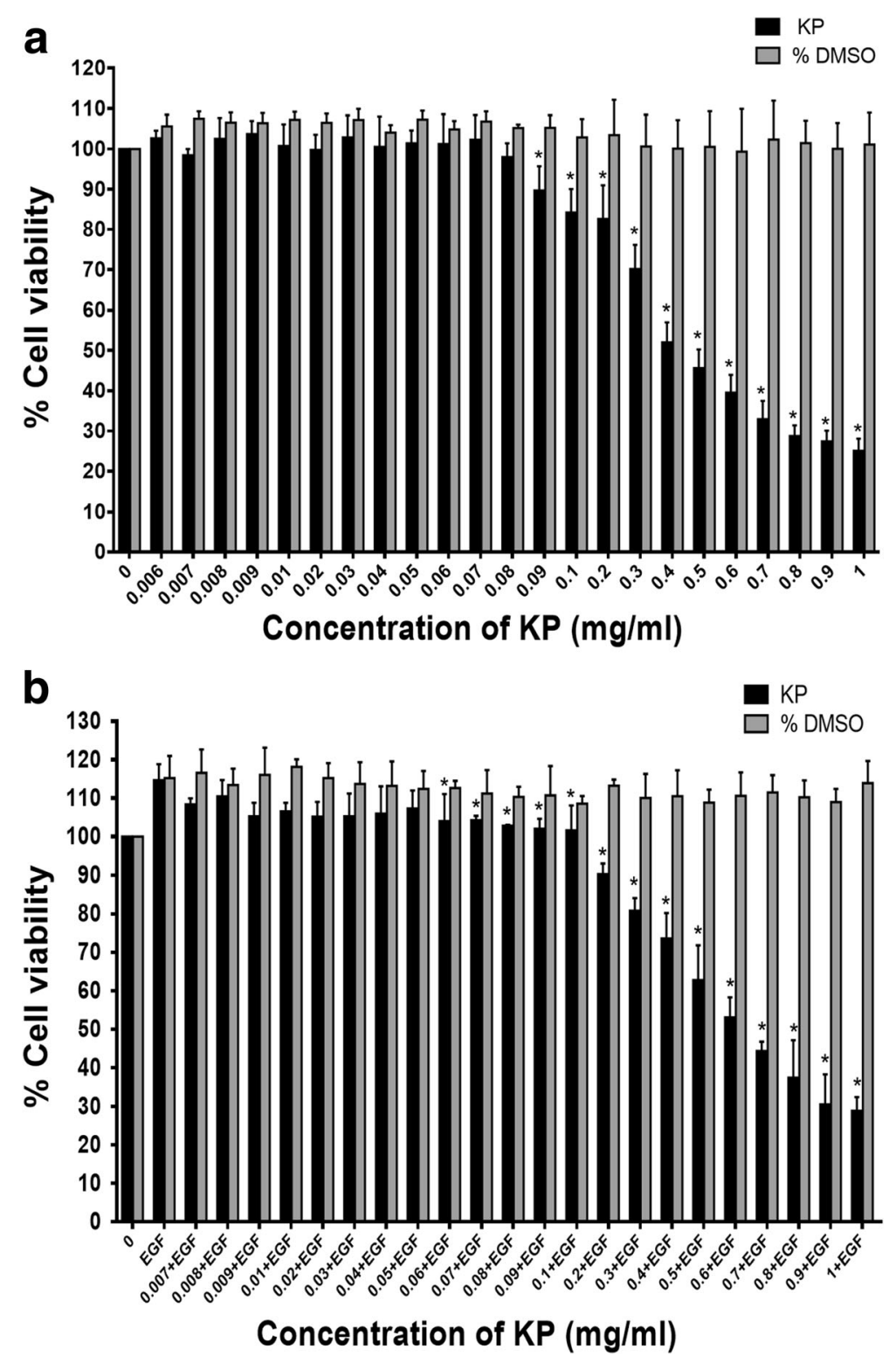

Fig. 1 The cytotoxicity effect of different concentrations of KP ethanol extract on SKOV3 cells without EGF (a) and with $100 \mathrm{ng} / \mathrm{mL}$ EGF (b). All data were from 3 independent experiments and reported as means \pm SD of each quadruplicate ${ }^{*} P<0.05$ compared to the control (untreated and EGF)

phosphorylation (2.6 fold), KP at 0.01 and $0.05 \mathrm{mg} / \mathrm{mL}$ was able to reduce the phosphorylation of ERK1/2 to 2.38 \pm 0.22 and $2.21 \pm 0.23$, respectively. Moreover, KP extract at 0.01 and $0.05 \mathrm{mg} / \mathrm{mL}$ reduced the phosphorylation of AKTto $0.87 \pm 0.04$ and $0.58 \pm 0.03$ without the presence of EGF and to $0.89 \pm 0.04$ and $0.7 \pm 0.07$ with the presence of EGF, respectively.

The effect of KP on inducing apoptotic cell death

Since cell viability assay showed cytotoxicity of KP extract at the concentrations over $0.1 \mathrm{mg} / \mathrm{mL}$. We thus examined whether KP extract increases cell death by using trypan blue exclusion test. We found that cells treated with KP extract at 0.1 and $0.25 \mathrm{mg} / \mathrm{mL}$ significantly increased cell death after $24 \mathrm{~h}$ of incubation. The percentage of cell death was $15.67 \pm 2 \%$ and $26.33 \pm 3.5 \%$ with $\mathrm{KP}$ treatment at 0.1 and $0.25 \mathrm{mg} / \mathrm{mL}$, respectively (Fig. 6a). Importantly, with the presence of EGF $100 \mathrm{ng} / \mathrm{mL}, \mathrm{KP}$ extract at 0.1 and $0.25 \mathrm{mg} / \mathrm{mL}$ was able to induce cell death to $13.17 \pm$ $1.8 \%$ and $21.25 \pm 2 \%$. In order to confirm whether dead cells were apoptotic cell, fluorescence nuclear staining using Hoechst 33342 was performed after treating cells with KP for $6 \mathrm{~h}$. Figure $6 \mathrm{c}$ showed nuclear fragmentation of SKOV3 cells treated with KP extract at 0.3 and $0.5 \mathrm{mg} / \mathrm{mL}$. 

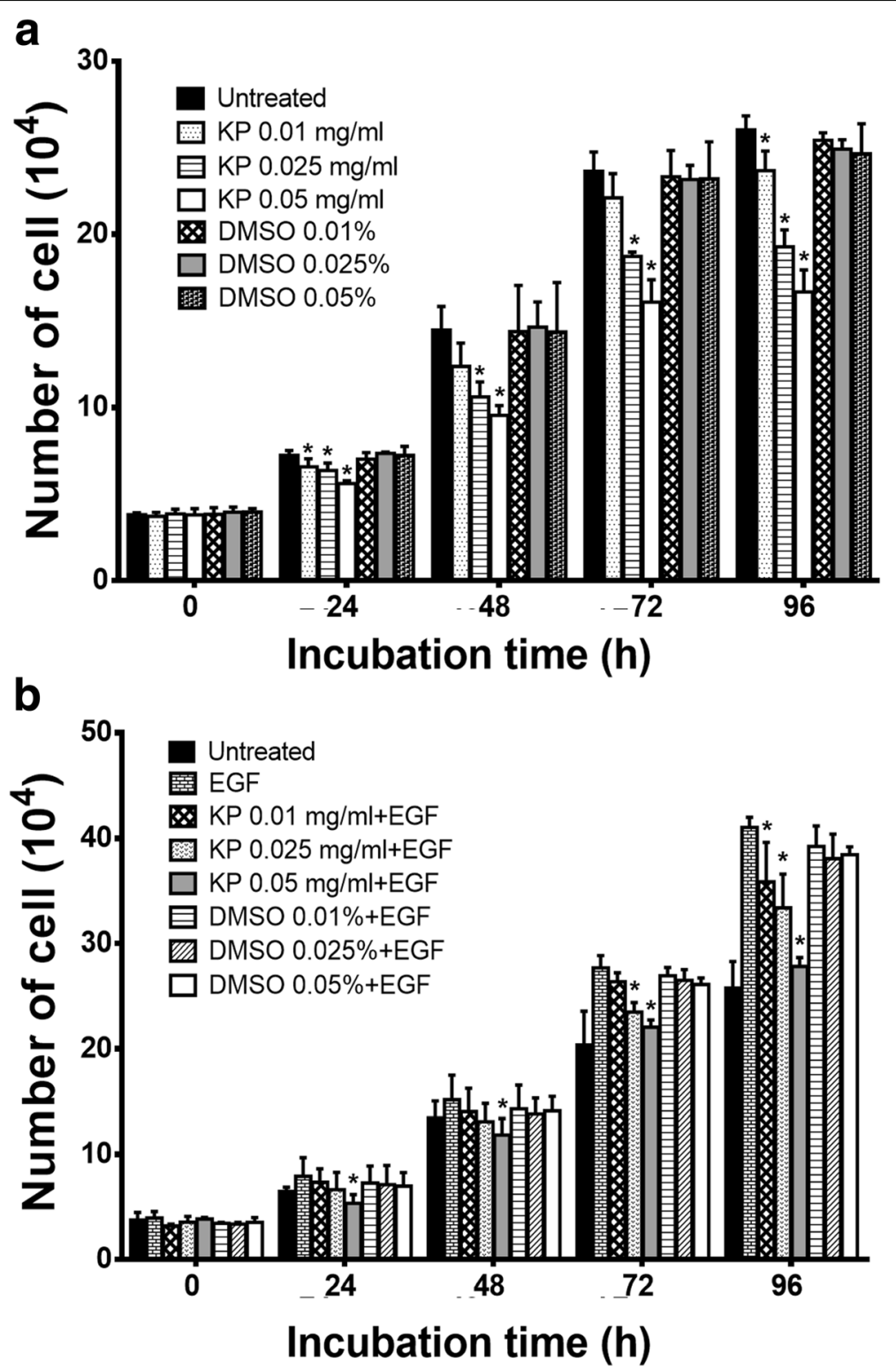

Fig. 2 The number of SKOV3 cells treated with non-toxic concentrations of KP $(0.01,0.025,0.05 \mathrm{mg} / \mathrm{mL})$ without EGF (a) and with $100 \mathrm{ng} / \mathrm{mL}$ EGF (b) at 24, 48, 72 and $96 \mathrm{~h}$. Data are expressed as mean \pm SD $(n=3) .{ }^{*} P<0.05$ as compared to untreated (a) or EGF (b)

This effect was seen in cells treated with DMSO. Based on this observation, we speculated that KP extract induces cell death via apoptosis machinery. We next determined apoptotic event by performing AnnexinV and PI fluorescent staining and detecting with flow cytometer. We found that cells treated with $\mathrm{KP}$ extract at 0.3 and $0.5 \mathrm{mg} / \mathrm{mL}$ increased apoptosis to $22.13 \pm 7.6 \%$ and $41.13 \pm 19.15 \%$, respectively (Fig. 7a, b). We further examined the activation of caspase- 9 , caspase- 3 , and caspase- 7 by western blot analysis and found that the full length of all caspases was significantly reduced in a concentration-dependent manner (Fig. 7c, d). These data strongly suggest that KP induces cell death via the activation of apoptotic cell death.

\section{Discussion}

Ovarian cancer is the most common cause of cancer death among other gynecologic cancers [14]. No obvious symptoms are present at the early stage, thus, most of patients are diagnosed when cancer is in an advanced stage which gives rise to poor response to chemotherapies [15]. Staging is an important factor determining prognosis and clinical outcome. Stage I, is defined as tumor is confined in the ovary. This stage shows overall survival of approximately 84 months. In particular, stage IV has much less overall survival rate of only 10 months [15]. The survival rate is not only related to stages of the disease but also associated with ovarian cell types. Several cell types 


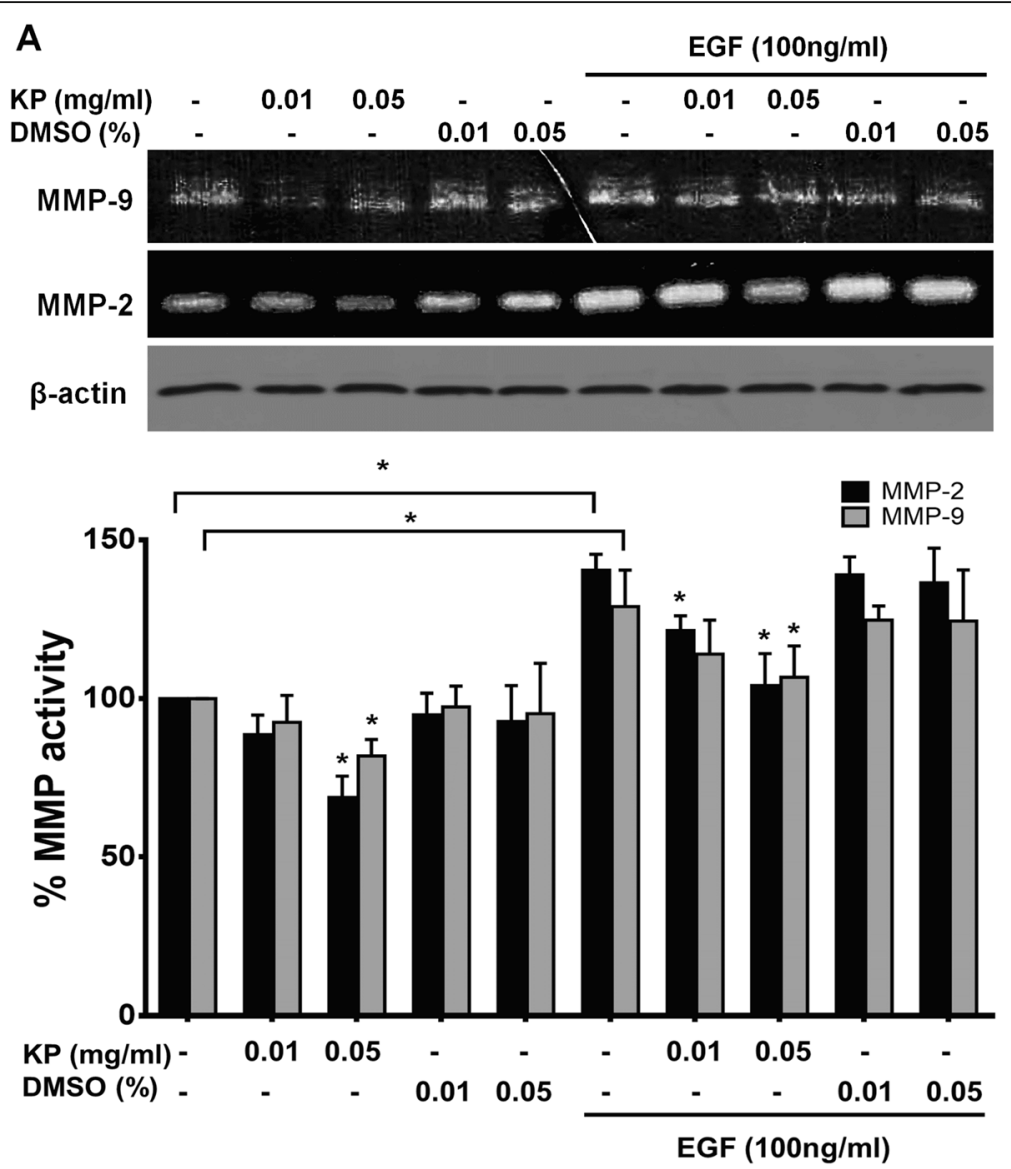

Fig. 3 The effect of KP ethanol extract on MMP-9 and MMP-2 activity. Gelatin zymogram showing MMP9 and MMP2 activities (a), Immunoreactive bands of $\beta$-actin was used as a loading control. Histogram of MMP-2 and MMP-9 activity is presented as percent of activity (b). All data were from 3 independent experiments. ${ }^{*} P<0.05$

have been identified in ovarian cancer. The most common histologic subtype is high-grade serous adenocarcinoma which has the worst prognosis $[16,17]$. We are particularly interested in using a high-grade serous adenocarcinoma, SKOV3, cell line as a model for investigating anticancer activity of Kaempferia parviflora in ovarian cancer.

We first performed cell viability assay to evaluate the cytotoxicity of KP extract in SKOV3 cells. It was found that KP extract decreased cell viability of ovarian cancer in a concentration-dependent manner with IC50 of approximately $0.5 \mathrm{mg} / \mathrm{mL}$, which was slightly higher than the previously reported IC50 of KP in cervical cancer cell line, HeLa [10]. Interestingly, KP extract also strongly exhibited the reduction of ovarian cancer cell viability in the presence of EGF, suggesting that KP has potent cytotoxic effects, which overcome the influence of EGF in maintaining cell viability. We further discovered that treating cells with KP extract at non-toxic concentrations (with or without the presence of EGF) at various time points could significantly inhibit number of cells in a concentration-dependent manner. Therefore, the doubling time was increased to approximately $1.3-1.4$ folds compared to untreated SKOV3 cells. This observation suggests that KP extract may suppress SKOV3 cell proliferation. According to cell viability results, the non-toxic concentrations were chosen for further experiments.

Since SKOV3 cells are known to be a high grade serous adenocarcinoma which has been reported to have high metastatic rate $[16,18]$. One major factor that plays important roles in cell invasion and metastasis is matrix metalloproteinase (MMP). Extensive evidence has been shown that the increased MMP level correlates with tumor progression and metastasis, especially in advanced ovarian serous cancers $[19,20]$. MMP expression, particularly MMP-2 and MMP-9, has been shown to have clinical association with progression of ovarian cancer [21, 22]. MMPs degrade various components of the extracellular matrix and play a crucial role in tumorigenesis, migration, invasion, and metastasis [23], and inhibition of MMPs by specific inhibitors has been demonstrated to markedly suppress tumor invasion and metastasis [24, 25]. Based on these previous reports, we hypothesized that KP extract 


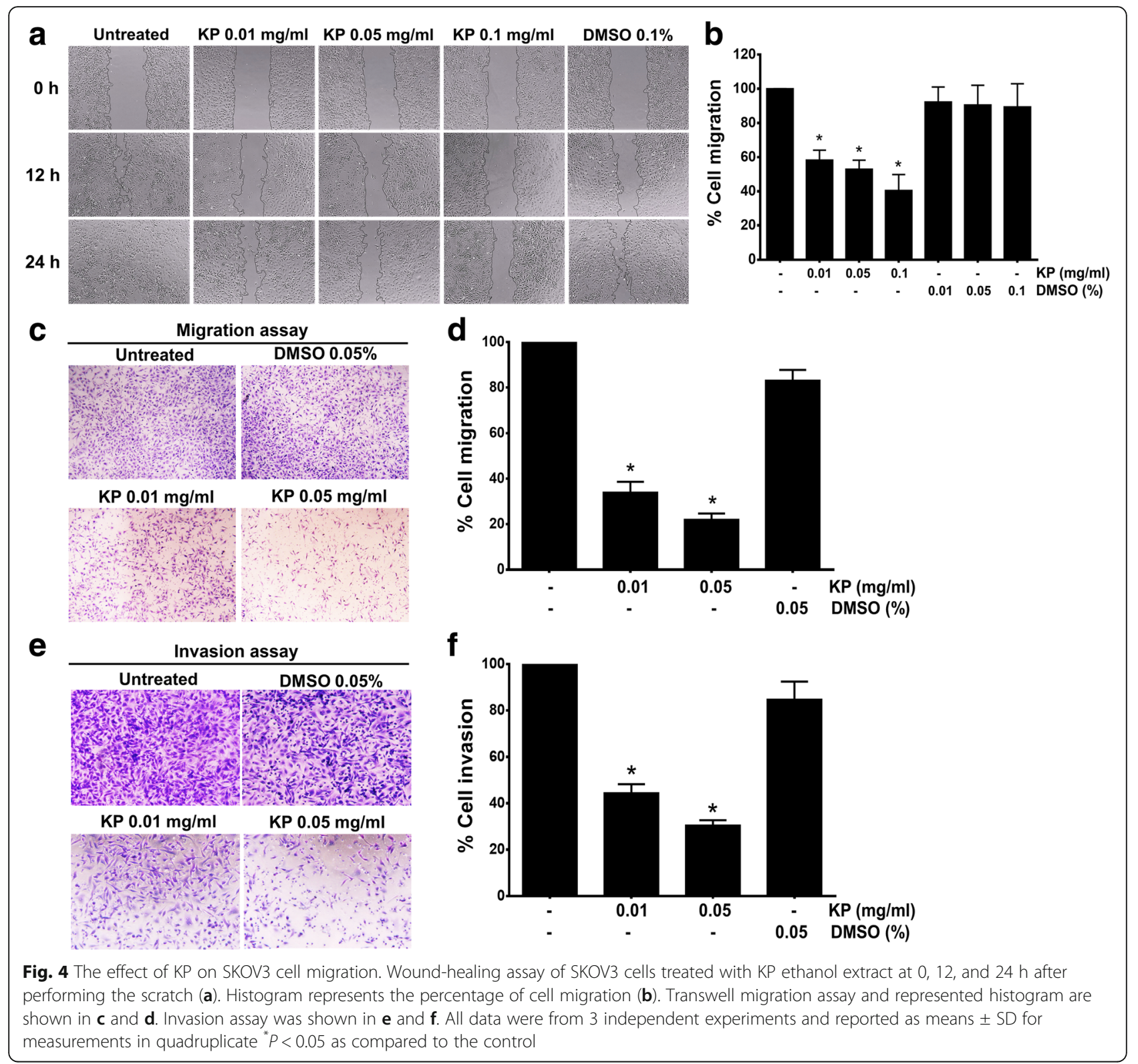

may be able to modulate the expression of MMPs. Undoubtedly, our zymographic study revealed that KP extract dramatically inhibited the activity of MMP-2 and MMP-9 in a concentration-dependent manner in SKOV3 cells. The ability of KP extract in suppressing the activity of MMPs was independent on the presence of EGF, since KP extract could be able to strongly overcome the effects of EGF. Our findings are in line with our previous studies showing that KP suppressed MMP-2 production in cervical cancer, HeLa cells [10]. Similar observation was reported in colorectal carcinoma cells, where a flavonoid, myricetin, inhibited MMP-2 activity and cell invasion [26]. These let us to believe that KP extract may also be able to reduce cancer cell migration and invasion. We, therefore, further investigated the effects of KP extract on cell migration and invasion.

Generally, cancer cell migration is involved in altering the cell-matrix interface on the cell surface [27]. The overexpression of MMPs could enhance cell migration [28], whereas the inhibition of MMP activity or overexpression of tissue inhibitor of metalloproteinases (TIMPs) resulted in a decrease in cancer cell migration [29]. Our results from wound healing assays showed that KP extract suppressed cell migration of SKOV3 cells in a concentration-dependent manner. Furthermore, the migratory function of cells was confirmed by Transwell migration showing that KP extract drastically inhibited migration and invasion of SKOV3 cells. The results from invasion assay with the presence of 


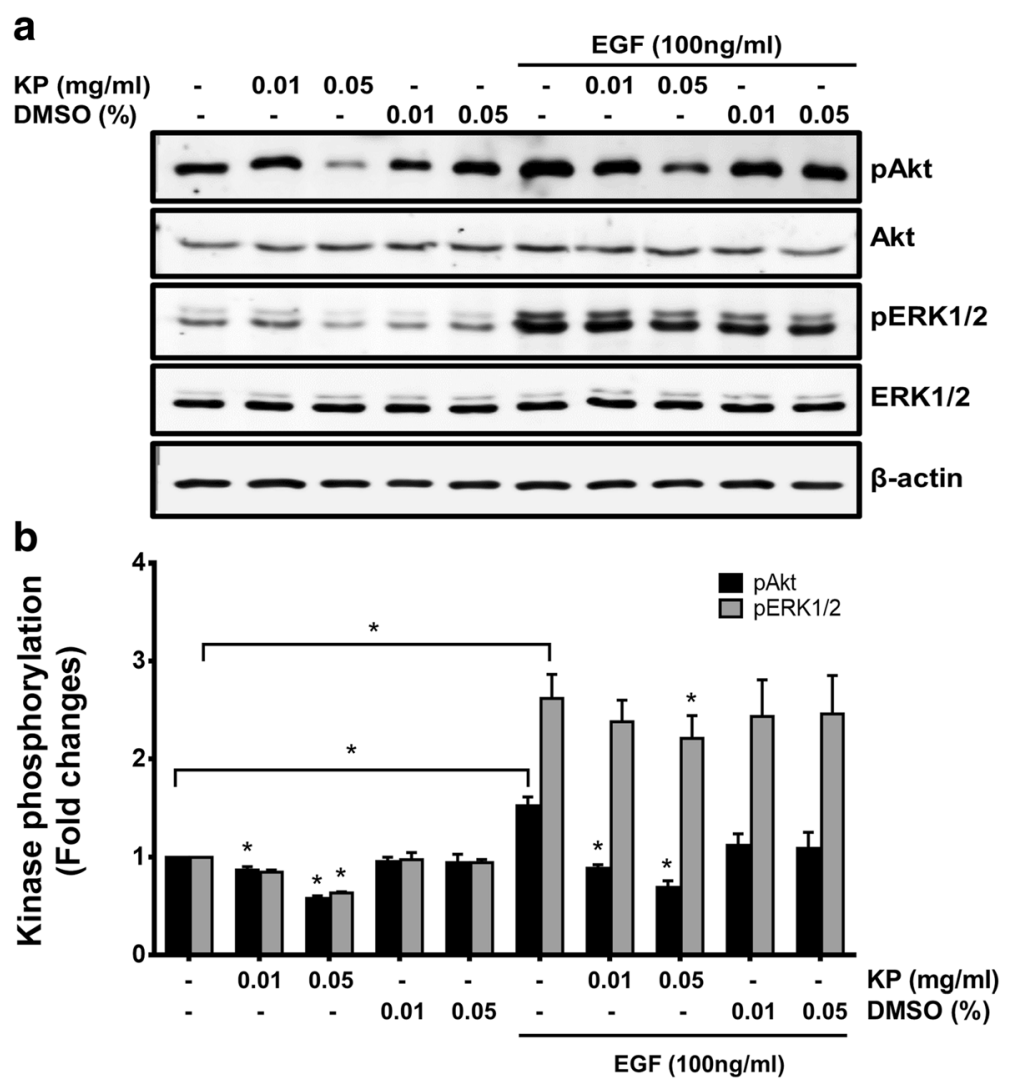

Fig. 5 The effect of KP on the PI3K/AKT and EKR1/2 MAPK signal transduction in SKOV3 cells. The immunoreactive bands of pAKT, AKT, pERK1/2 and ERK1/2 (a). Histogram of phosphorylation level of AKT and ERK1/2 (b). $\beta$-actin was used as a loading control. Data expressed as mean \pm SD $(n=3) .{ }^{*} P<0.05$

matrigel definitively verified that KP extract could be able to suppress invasion of SKOV3 cells. Together, these results strongly suggest that KP possesses the inhibitory effect on migration and invasion of SKOV3. These observations are consistent with the zymography results, suggesting that the reduced activity of MMPs may greatly contribute to the reduction of cancer cell invasion and migration.

Besides the ability of KP extract on an aspect of suppressing ovarian cancer cell metastasis, we would also like to explore its effect on ovarian cancer cell growth and survival. In particular, since SKOV3 cells apparently express EGF receptor (EGFR) [30], we therefore examined whether $\mathrm{KP}$ extract can overcome the influence of EGF on activating molecular signal transduction pathways relevant to cell growth and survival. EGFR is involved in cell proliferation, motility, adhesion, angiogenesis, and survival via the activation of phosphatidylinositol-3 kinase (PI3K/AKT) pathway, and the extracellular signal-regulated kinase (ERK) pathway [31]. EGFR is widely expressed in 33-75\% of ovarian cancer and has been implicated in the growth and progression of this cancer [32-34]; therefore, EGFR is important to represent a potential target for anticancer drug development. An example of EGFR-directed monoclonal antibody is cetuximab, which inhibits cell growth in OVCAR-2 cells, whereas the growth of SKOV3 cells is not affected [35]. Another class of EGFR inhibitor is a group of small molecule tyrosine kinase inhibitors that target the receptor catalytic domain of EGFR. Those include gefitinib and erlotinib [36]. AKT and ERK are major downstream signaling molecules of EGFR [37]. Previous evidence demonstrated that KP extract significantly suppressed the phosphorylation of PI3K, AKT, ERK1/2, and Elk1 in HeLa cells [10], thus we hypothesized whether KP extract can suppress the activation of ERK1/2 and AKT signaling in high grade serous ovarian cancers. Our study clearly showed that KP extract markedly suppressed phosphorylation of ERK1/2 and AKT. This observation was still seen when the experiment was performed with the presence of EGF. The present results indicate that KP extract suppresses ERK1/2 pathway which is normally involved in cell proliferation, and the extract suppressed AKT pathway which plays roles in cell survival. A study in Drosophila showed that a gain-of-function mutation that results in enhanced ERK1/ 2 signaling capabilities could support ERK1/2 activation 

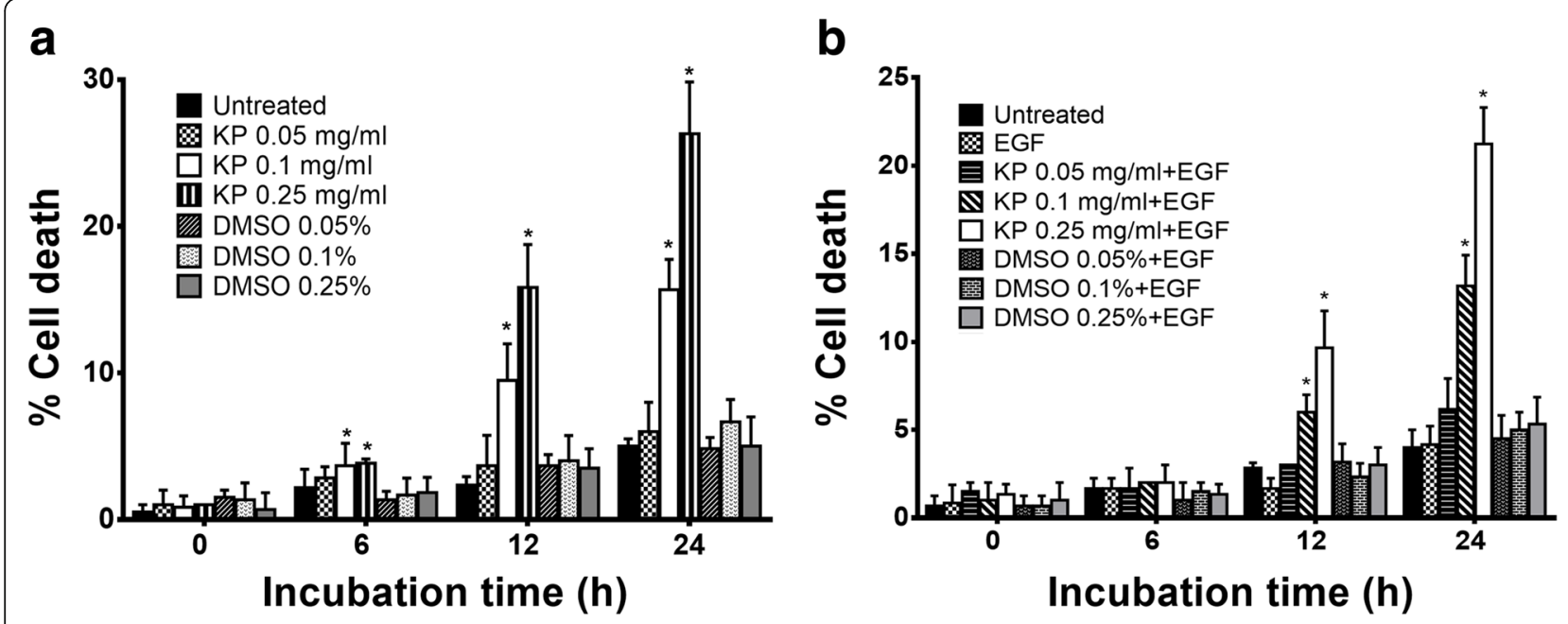

\section{DMSO $0.5 \%$}

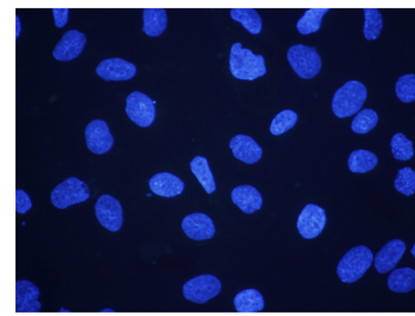

$\mathrm{KP} 0.1 \mathrm{mg} / \mathrm{ml}$

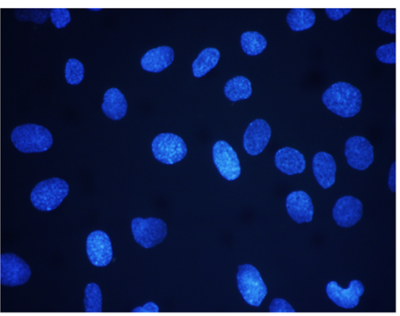

$\mathrm{KP} 0.3 \mathrm{mg} / \mathrm{ml}$

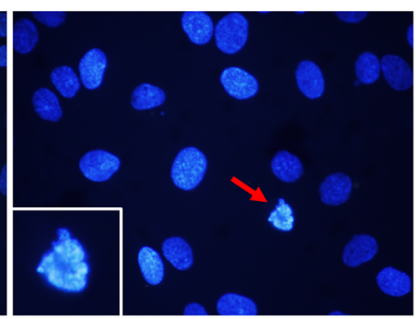

$\mathrm{KP} 0.5 \mathrm{mg} / \mathrm{ml}$

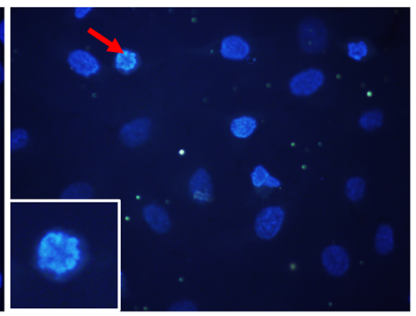

Fig. 6 The effect of KP on cell death in SKOV3 cells by trypan blue exclusion assay. Percent of cell death of cells treated with KP without EGF (a) and with $100 \mathrm{ng} / \mathrm{mL}$ EGF (b). Data presented as means $\pm \mathrm{SD}, n=3,{ }^{*} P<0.05$ compared to DMSO control. The DNA staining (Hoechst 33342 ) of KP treated cells shows nuclear deformity $(\mathbf{c})$. The condensation of the nucleus was observed in KP ethanol extract treatments compared to the vehicle control DMSO. Original magnification, 400X

in the cancer cells [38]. Our findings are supported by recent studies showing that the use of RNA interference to silence ERK1/2 phosphorylation led to the complete suppression of tumor cell proliferation [39]. Since various cancers have aberrant regulation of AKT pathway that leads to prolonged survival of tumor [40], and previous studies showed that the inhibition of AKT activity is useful as a therapeutic approach for the therapy of cisplatin-resistant ovarian cancer because an activation of AKT promotes cisplatin-resistance [41, 42], we hope that KP may be a novel and effective agent that has some potential targets in AKT signaling and therefore may be beneficial for developing a cancer therapeutic means.

One of our key observations was an increase in cell death at $24 \mathrm{~h}$ after treatment with KP extract at toxic concentrations. Nuclear fragmentation, which is a result of the cleavage of chromosomal DNA into oligonucleosomal size fragments, is an integral part of apoptosis [43]. The cell apoptosis leads to deformity of nuclear lamina, and consequently increases active caspases [44]. Therefore, to confirm whether these dead cells were apoptotic cells, we stained SKOV3 cells with Hoechst 33342 and observed nuclear fragmentation of SKOV3 cells treated with KP extract. This finding is consistent with Potikanond et al. (2017) indicating that nuclear deformity and nuclear fragmentation were induced by KP treatment in HeLa cells. In addition, the apoptotic event of KP-treated SKOV3 was further determined by Annexin V/PI and flow cytometry analysis. Clearly, our results showed that KP significantly induced apoptosis in SKOV3 cells in a concentration-dependent manner. To confirm our hypothesis that KP extract induces apoptosis in ovarian cancer cells, we specifically analyzed the key apoptosis execution enzymes, caspase-3, caspase-7, and caspase- 9 in SKOV3 cells treated with KP extract. The results showed that the full-length structure of all caspases was reduced in a concentration-dependent manner in SKOV3 cells treated with KP extract, implicating that SKOV3 cell death in KP treatment was possessed through programed cell death signaling pathway.

\section{Conclusions}

The current study demonstrated that KP extract has anti-cancer properties against a high grade serous 


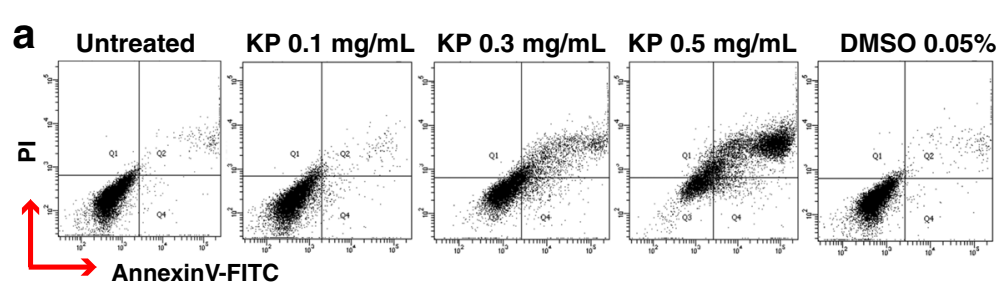

b

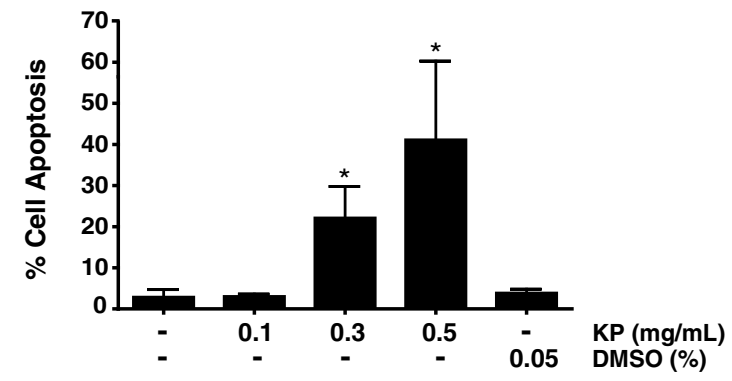

C

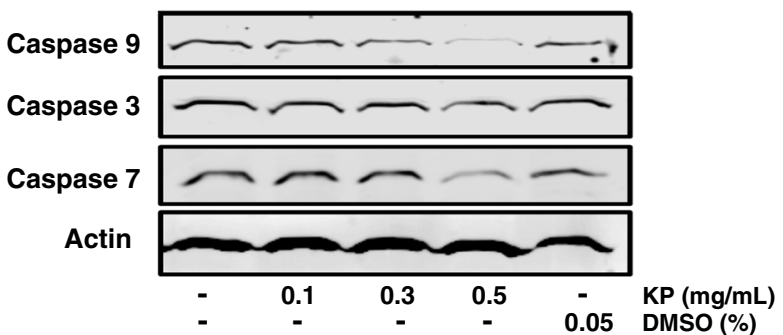

d

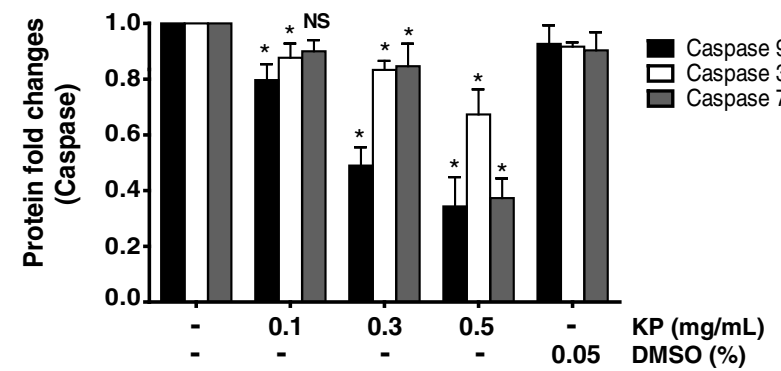

Fig. 7 The effect of KP ethanol extract on apoptosis and caspases in SKOV3 cells. Annexin V-FITC and PI labeling in KP treated cells was measured by flow cytometer (a) and histogram of percent of apoptotic cells is shown in $\mathbf{b}$. The level of caspase-3, -9 , and -7 by western blotting are shown in $\mathbf{c}$. Histogram of relative intensity of full-length of caspase-3, - -9, and -7. $\beta$-actin is used as a protein loading control (d). These data are represented as mean \pm SD of three replicates. ${ }^{*} P<0.05$ indicates significant difference compared to control

adenocarcinoma, SKOV3. Specifically, even though SKOV3 cells are every aggressive and resistant to many chemotherapeutic agents, our results showed that KP extract was able to suppress the activity of MMP-2 and MMP-9, migration and invasion, activation of growth and survival signal transduction pathways, and induction of apoptotic cell death. These observations convince us to believe that KP extract is a potential agent to be further developed as an effective therapy for ovarian cancer.

\section{Abbreviations}

DMSO: Dimethyl sulfoxide; EGF: Epidermal growth factor; KP: Kaempferia parviflora; MMP : Matrix metalloproteinase

\section{Acknowledgements}

We thank Mr.Sathit Monkaew for assistance with laboratory support.

\section{Funding}

This work was supported by CMB funding, Faculty of Medicine, Chiang Mai University (SPO) and the Center for Innovation in Chemistry (PERCH-CIC), Commission on Higher Education, Ministry of Education (at Faculty of Science, Mahidol University, Thailand) (SPO). We also are thankful for the supports from the Thailand Research Fund (MRG6080193) (WN) and Plant Genetic Conservation Project under the Royal Initiation of Her Royal

Highness Princess Maha Chakri Sirindhorn (RSPG) (SS and CS), and Research Center of Pharmaceutical Nanotechnology, Chiang Mai University (SPO) for partial financial support. The funders had no role in the project design, data collection, interpretation, or decision to publish.

\section{Availability of data and materials}

The datasets used and/or analysed during the current study available from the corresponding author on reasonable request.

\section{Authors' contributions}

Plant cultivation, collection, harvesting, and identification were conducted by SS and CS. PM prepared the plant extract. The experiments, data analysis, 
and manuscript writing were conducted by SPA and MNT. SPO and WN funded the research project, designed, performed the experiments, prepared the manuscript, and contributed to the funding of the project. All authors have read and approved the manuscript.

\section{Ethics approval and consent to participate}

Not applicable.

\section{Competing interests}

The authors declare that they have no competing interests.

\section{Publisher's Note}

Springer Nature remains neutral with regard to jurisdictional claims in published maps and institutional affiliations.

\section{Author details}

1 Department of Pharmacology, Faculty of Medicine, Chiang Mai University, Chiang Mai 50200, Thailand. ' Graduate School, Chiang Mai University, Chiang Mai 50200, Thailand. ${ }^{3}$ Department of Microbiology, Faculty of Medicine, Chiang Mai University, Chiang Mai 50200, Thailand. ${ }^{4}$ Department of Chemistry, Faculty of Science, Chiang Mai University, Chiang Mai 50200, Thailand. ${ }^{5}$ Environmental Science Program, Faculty of Science, Chiang Mai University, Chiang Mai 50200, Thailand.

\section{Received: 23 November 2017 Accepted: 25 May 2018}

Published online: 11 June 2018

\section{References}

1. Waldmann A, Eisemann N, Katalinic A. Epidemiology of Malignant Cervical, Corpus Uteri and Ovarian Tumours - Current Data and Epidemiological Trends. Geburtshilfe Frauenheilkd. Thieme Medical Publishers; 2013 [cited 2017 Nov 14]:73:123-9.

2. Siegel RL, Miller KD, Jemal A. Cancer statistics, 2017. CA Cancer J Clin. 2017 [cited 2018 May 10];67:7-30.

3. Jelovac D, Armstrong DK. Recent progress in the diagnosis and treatment of ovarian cancer. CA Cancer J Clin. NIH Public Access. 2011:61:183-203.

4. Vang R, Shih I-M, Kurman RJ. Ovarian low-grade and high-grade serous carcinoma: pathogenesis, clinicopathologic and molecular biologic features, and diagnostic problems. Adv Anat Pathol. NIH Public Access. 2009;16:267-82.

5. Kurman RJ. Origin and molecular pathogenesis of ovarian high-grade serous carcinoma. Ann Oncol. 2013;24:x16-21.

6. Mukhtar E, Adhami VM, Mukhtar H. Targeting microtubules by natural agents for cancer therapy. Mol Cancer Ther. NIH Public Access. 2014;13:275-84

7. Yenjai C, Prasanphen K, Daodee S, Wongpanich V, Kittakoop P. Bioactive flavonoids from Kaempferia parviflora. Fitoterapia. 2004;75:89-92.

8. Patanasethanont D, Nagai J, Matsuura C, Fukui K, Sutthanut K, Sripanidkulchai $B$, et al. Modulation of function of multidrug resistance associated-proteins by Kaempferia parviflora extracts and their components. Eur J Pharmacol. 2007:566:67-74.

9. Banjerdpongchai R, Chanwikruy Y, Rattanapanone V, Sripanidkulchai B. Induction of apoptosis in the human leukemic U937 cell line by Kaempferia parviflora Wall.ex.Baker extract and effects of paclitaxel and camptothecin. Asian Pac J Cancer Prev. 2009;10:1137-40.

10. Potikanond S, Sookkhee S, Na Takuathung M, Mungkornasawakul P, Wikan $\mathrm{N}$, Smith DR, et al. Kaempferia parviflora extract exhibits anti-cancer activity against HeLa cervical Cancer cells. Front Pharmacol. 2017;8:630.

11. Hudson LG, Zeineldin R, Silberberg M, Stack MS. Activated epidermal growth factor receptor in ovarian cancer. Cancer Treat Res. NIH Public Access. 2009;149:203-26.

12. Catasús L, Bussaglia E, Rodríguez I, Gallardo A, Pons C, Irving JA, et al. Molecular genetic alterations in endometrioid carcinomas of the ovary: similar frequency of beta-catenin abnormalities but lower rate of microsatellite instability and PTEN alterations than in uterine endometrioid carcinomas. Hum Pathol. 2004;35:1360-8.

13. Mandai M, Konishi I, Kuroda H, Komatsu T, Yamamoto S, Nanbu K, et al. Heterogeneous distribution of K-ras-mutated epithelia in mucinous ovarian tumors with special reference to histopathology. Hum Pathol. 1998;29:34-40.

14. Wilailak S. Epidemiologic report of gynecologic cancer in Thailand. J Gynecol Oncol. Korean Society of Gynecologic Oncology and Colposcopy. 2009;20:81.
15. Cristea M, Han E, Salmon L, Morgan RJ. Review: practical considerations in ovarian cancer chemotherapy. Ther Adv Med Oncol. 2010;2:175-87.

16. Anglesio MS, Wiegand KC, Melnyk N, Chow C, Salamanca C, Prentice LM, et al. Type-specific cell line models for type-specific ovarian cancer research. PLoS One. 2013;8:e72162.

17. Reid BM, Permuth JB, Sellers TA. Epidemiology of ovarian cancer: a review. Cancer Biol Med. Chinese Anti-Cancer Association. 2017;14:9-32.

18. Beaufort CM, Helmijr JCA, Piskorz AM, Hoogstraat M, Ruigrok-Ritstier K, Besselink N, et al. Ovarian Cancer cell line panel (OCCP): clinical importance of in vitro morphological subtypes. Pearson R, editor. PLoS One. 2014;9:e103988.

19. Garzetti GG, Ciavattini A, Lucarini G, Goteri G, De Nictolis M, Garbisa S, et al. Tissue and serum metalloproteinase (MMP-2) expression in advanced ovarian serous cystoadenocarcinomas: clinical and prognostic implications. Anticancer Res. 1995;15:2799-804.

20. Fishman DA, Bafetti LM, Banionis S, Kearns AS, Chilukuri K, Stack MS Production of extracellular matrix-degrading proteinases by primary cultures of human epithelial ovarian carcinoma cells. Cancer. 1997:80:1457-63.

21. Lopata A, Agresta F, Quinn MA, Smith C, Ostor AG, Salamonsen LA. Detection of endometrial cancer by determination of matrix metalloproteinases in the uterine cavity. Gynecol Oncol. Academic Press. 2003;90:318-24.

22. Torng P-L, Mao T-L, Chan W-Y, Huang S-C, Lin C-T. Prognostic significance of stromal metalloproteinase-2 in ovarian adenocarcinoma and its relation to carcinoma progression. Gynecol Oncol. 2004;92:559-67.

23. Bauvois B. New facets of matrix metalloproteinases MMP-2 and MMP-9 as cell surface transducers: outside-in signaling and relationship to tumor progression. Biochim Biophys Acta. Rev. Cancer. 2012;1825:29-36.

24. Liotta LA, Tryggvason K, Garbisa S, Hart I, Foltz CM, Shafie S. Metastatic potential correlates with enzymatic degradation of basement membrane collagen. Nature. Nature Publishing Group. 1980;284:67-8.

25. Stetler-Stevenson WG. The role of matrix metalloproteinases in tumor invasion, metastasis, and angiogenesis. Surg Oncol Clin N Am. 2001;10:383-92.

26. Ko C-H, Shen S-C, Lee TJF, Chen Y-C. Myricetin inhibits matrix metalloproteinase 2 protein expression and enzyme activity in colorectal carcinoma cells. Mol. Cancer Ther. American association for. Cancer Res. 2005:4:281-90.

27. Kim YH, Kwon H-J, Kim D-S. Matrix metalloproteinase 9 (MMP-9)-dependent processing of ßig-h3 protein regulates cell migration, invasion, and adhesion. J Biol Chem. American Society for Biochemistry and Molecular Biology. 2012:287:38957-69.

28. Deryugina El, Luo GX, Reisfeld RA, Bourdon MA, Strongin A. Tumor cell invasion through matrigel is regulated by activated matrix metalloproteinase-2. Anticancer Res. 1997;17:3201-10.

29. George SJ, Johnson JL, Angelini GD, Newby AC, Baker AH. Adenovirusmediated gene transfer of the human TIMP-1 gene inhibits smooth muscle cell migration and Neointimal formation in human saphenous vein. Hum Gene Ther. 1998:9:867-77.

30. Sewell JM, Macleod KG, Ritchie A, Smyth JF, Langdon SP Targeting the EGF receptor in ovarian cancer with the tyrosine kinase inhibitor ZD 1839 (\&quot; Iressa\&quot;). Br J Cancer. Nature Publishing Group; 2002;86:456-62.

31. Tanaka $Y$, Terai $Y$, Tanabe A, Sasaki H, Sekijima T, Fujiwara S, et al. Prognostic effect of epidermal growth factor receptor gene mutations and the aberrant phosphorylation of Akt and ERK in ovarian cancer. Cancer Biol Ther. 2011;11:50-7.

32. Berchuck A, Rodriguez GC, Kamel A, Dodge RK, Soper JT, Clarke-Pearson DL. Epidermal growth factor receptor expression in normal ovarian epithelium and ovarian cancer: II. Relationship between receptor expression and response to epidermal growth factor. Am J Obstet Gynecol. Mosby. 1991; 164:745-50.

33. Psyrri A, Kassar M, Yu Z, Bamias A, Weinberger PM, Markakis S, et al. Effect of epidermal growth factor receptor expression level on survival in patients with epithelial ovarian Cancer. Clin Cancer Res. 2005:11:8637-43.

34. Stadlmann S, Gueth U, Reiser U, Diener P-A, Zeimet AG, Wight E, et al. Epithelial growth factor receptor status in primary and recurrent ovarian cancer. Mod Pathol. Nature Publishing Group. 2006;19:607-10.

35. Bijman MNA, van Berkel MPA, Kok M, Janmaat ML, Boven E. Inhibition of functional HER family members increases the sensitivity to docetaxel in human ovarian cancer cell lines. Anti-Cancer Drugs. 2009;20:450-60.

36. Harari PM. Epidermal growth factor receptor inhibition strategies in oncology. Endocr Relat Cancer. 2004;11:689-708.

37. Bunn PA Jr and Franklin W. Epidermal growth factor receptor expression, signal pathway, and inhibitors in non-small cell lung cancer. Semin Oncol. 2002;29(5Suppl 14):38-44. 
38. Bott CM, Thorneycroft SG, Marshall CJ. The sevenmaker gain-offunction mutation in p42 MAP kinase leads to enhanced signalling and reduced sensitivity to dual specificity phosphatase action. FEBS Lett. 1994:352:201-5.

39. Steinmetz R, Wagoner HA, Zeng P, Hammond JR, Hannon TS, Meyers JL, et al. Mechanisms Regulating the Constitutive Activation of the Extracellular Signal-Regulated Kinase (ERK) Signaling Pathway in Ovarian Cancer and the Effect of Ribonucleic Acid Interference for ERK1/2 on Cancer Cell Proliferation. Mol. Endocrinol. [Internet]. Oxford University Press; 2004;18:2570-82.

40. Steelman LS, Stadelman KM, Chappell WH, Horn S, Bäsecke J, Cervello M, et al. Akt as a therapeutic target in cancer. Expert Opin Ther Targets. 2008; 12:1139-65.

41. Yang X, Fraser M, Abedini MR, Bai T, Tsang BK. Regulation of apoptosisinducing factor-mediated, cisplatin-induced apoptosis by Akt. Br J Cancer. 2008:98:803-8.

42. Peng D-J, Wang J, Zhou J-Y, Wu GS. Role of the Akt/mTOR survival pathway in cisplatin resistance in ovarian cancer cells. Biochem Biophys Res Commun. 2010;394:600-5.

43. Zhang JH, Ming M. DNA fragmentation in apoptosis. Cell Res. [Internet]. Nature Publishing Group. 2000;10:205-11.

44. Elmore S. Apoptosis: a review of programmed cell death. Toxicol Pathol. 2007:35:495-516.

Ready to submit your research? Choose BMC and benefit from:

- fast, convenient online submission

- thorough peer review by experienced researchers in your field

- rapid publication on acceptance

- support for research data, including large and complex data types

- gold Open Access which fosters wider collaboration and increased citations

- maximum visibility for your research: over $100 \mathrm{M}$ website views per year 